\section{Initial Identification and Sensitivity to Antimicrobial Agents of Salmonella sp. Isolated from Poultry Products in the State of Ceara, Brazil}

Author(s)

Oliveira WF'

Cardoso WM ${ }^{2 *}$

Salles RPR ${ }^{1}$

Romão $\mathrm{JM}^{3}$

Teixeira RSC

Câmara $\mathrm{SR}^{1}$

Siqueira $\mathrm{AA}^{3}$

Marques $\mathrm{LCL}^{4}$

Postgraduate students in Veterinary Sciences of Ceara State University

2 Professor Doctor of Veterinary Medicine School of Ceara State University

3 Undergraduate students of Veterinary Medicine School of Ceara State University

4 Veterinarian of the Laboratory of Animal Health of the Brazilian Ministry of Agriculture

\section{Mail Address}

William Maciel Cardoso

Av. Rogaciano Leite, 200 - Apt 1303

BI. Tulipe, Bairro Salinas

60810-000. Fortaleza, CE, Brazil

Phone/Fax: 55 (085) 2411307 or 2992748 or 99894742

E-mail: william.maciel@uol.com.br josueromao@yahoo.com.br

\section{Keywords}

Salmonella sp, identification, sensitivity, poultry products.

\section{ABSTRACT}

The objective of this research was to isolate and to verify the sensitivity to antimicrobial agents of strains of Salmonella sp. isolated from poultry products in the state of Ceara, Brazil. A total number of 114 samples was collected from 63 broiler carcasses derived from two processing plants and two supermarkets, and 51 excreta samples were collected in broiler farms located in the state of Ceara, which used three live production stages. Each excreta sample consisted of a fresh excreta pool from 100 birds. Samples were submitted to microbiological analyses, and the isolated Salmonella strains were tested for antimicrobial sensitivity. No Salmonella was isolated from excreta samples, while broiler carcass samples showed a high contamination rate of 11.8\%. Three serotypes were identified: Salmonella enterica serovar Enteritidis, 50\%; Salmonella enterica serovar Panama 33\%, and Salmonella enterica serovar Newport, $17 \%$. As to the susceptibility tests to antimicrobial agents, $100 \%$ of the isolated Salmonella strains showed resistance to Ampicillin and Tetracycline, and sensitivity to Gentamycin, Netilmycin, Carbenicillin, Chloramphenicol.

\section{INTRODUCTION}

Brazil is one of the largest broiler producers in the world. In order to maintain this annual productivity, rational management emphasizing the quality of poultry products is necessary. For this purpose, the government has implemented health programs aiming at controlling diseases that cause economic and health problems. General prophylactic procedures and biological security practices applied in every stage of broiler production (broiler grand-parent farms, broiler parent farms, commercial broiler chick farms, and hatcheries) decrease, but do not prevent the presence of bacteria. Among the pathogenic microorganisms in industrial poultry production, the genus Salmonella is of paramount importance.

In terms of public health, there are Salmonella strains that may cause paratyphoid infection, as well as Salmonella enteritidis, Salmonella typhimurium, Salmonella infantis, and Salmonella agona, which are important sources of food-borne illnesses. These bacteria are not related to specific diseases, and are capable of infecting indistinctly several animal species, including humans (Lax et al., 1995). The importance of Salmonella in the public health is very significant; for instance, it accounted for nearly $84 \%$ of food-borne human illnesses in Scotland from 1980 to 1989 (Oboegbulem et al., 1993), and 81\% in Italy from 1991 to 1994 (Scuderi et al., 1996). According to the Centers for Disease Control and Prevention in United States, Salmonella is responsible for 1.34 million of cases of disease, 16.430 hospitalizations, and 582 deaths each year (Mead et al., 1999). The total annual cost resulting from food- 
Oliveira WF, Cardoso WM, Salles

RPR, Romão JM, Teixeira RSC,

Câmara SR, Siqueira AA, Marques

LCL

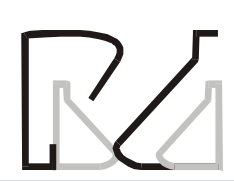

Initial Identification and Sensitivity to Antimicrobial Agents of Salmonella sp. Isolated from Poultry Products in the State of Ceara, Brazil

borne Salmonella infections in United States is estimated in about US\$3.5 billion (Pathogen, 1995).

The epidemiology of Salmonella infections in birds is very complex (Hinton, 1988), and it is difficult to determine how a flock was infected, or how the dissemination occurred in the flock. Hong'ombe et al. (1999) identified S. enteritidis in broiler carcasses ready for market in several different situations. Many authors identified poultry products as sources of infection of Salmonella that causes enteritis in humans (Dhillon et al., 2001). Approximately $10 \%$ of salmonellosis cases are caused by poultry meat, and in the United States, there are between 15 and 20 cases of salmonellosis for each 100,000 people (Bryan \& Doyle, 1995). According to Skov et al. (2002), the number of diagnosed cases of salmonellosis in humans in Denmark increased during the last decade, and the serotypes $S$. enteritidis and $S$. typhimurium were the most commonly isolated strains. Major outbreaks of human salmonellosis were caused by the consumption of incorrectly manipulated foods in restaurants and institutional kitchens. Undercooked food, slow freezing, and keeping foods for many hours under no refrigeration are considered as contributing factors for the emergence of this disease in humans (Costa, 1996).

In spite of the programs of Brazilian Agriculture Ministry to control poultry pathogens, there are reports of outbreaks of salmonellosis, and later detection of the pathogen in broiler carcasses and foods containing eggs in Brazil. The main factors of this contamination are improper handling of these products in some companies, the epidemiologic complexity of Salmonella, and deficient inspection during production, processing, and trade of animal products. However, studies on the contamination of broilers with Salmonella are practically null in our region.

Due to the need to constantly monitor of the health quality of birds for human consumption, this study aimed at isolating and identifying Salmonella serotypes present during live production, and trading of chicken meat, as well as the behavior of Salmonella spp. strains relative to common antimicrobial drugs.

\section{MATERIALS AND METHODS}

\section{Collection of excreta samples during live production}

A total number of 63 excreta samples were collected from 21 broiler flocks in three management stages: starter ( 1 day of age), grower (20 days of age), and finisher (45 days of age), from broiler companies located in the state of Ceara. Each sample consisted of a fresh excreta pool from 100 birds, randomly collected in commercial broiler houses. The collected samples were placed in sterile plastic bags, and were submitted to the laboratory, following the criteria recommended by the National Poultry Health Program - PNSA (Brazil/MAARA, 2002).

\section{Collection of samples from broilers carcasses at retail}

Broiler carcasses were collected from sales points and processing plants, and were divided into the following categories: fresh carcasses (14 samples), collected in two processing plants with no federal sanitary inspection (7 carcasses in each plant); refrigerated carcasses (18 samples), ten in one supermarket and eight in another; and frozen carcasses (19 samples), ten samples collected in one supermarket, and nine from another.

\section{Microbiological analyses}

The excreta samples (live production phase) and the carcasses were randomly collected during typical management, slaughter, and sales days.

Feces samples weighing $25 \mathrm{~g}$ were diluted in 225 $\mathrm{mL}$ of buffered peptone water at $0.1 \%$, and carcass samples were submitted to the "carcass wash" method, through the addition of $300 \mathrm{~mL}$ of buffered peptone water at $0.1 \%$, as described by Cox et al. (1978), and then placed in Erlenmeyer flasks.

Bacterial culture followed the procedures established by National Poultry Health Program - PNSA (Brasil/MAARA, 2002) with some modifications. The protocol started with pre-enrichment: the solutions resulting from the process "carcass wash" were incubated at $37{ }^{\circ} \mathrm{C}$ for 24 hours. Aliquots from preenrichment were inoculated into selective enrichment liquid media at a ratio of 1/100 in Rappaport-Vassiliadis broth and at1/10 in Selenite-Cysteine broth. A loopful of each broth was streaked on plates of Brilliant Green agar, MacConkey agar, and Salmonella-Shigella agar. The temperature and the period of incubation were standardized at $37^{\circ} \mathrm{C}$ for 24 hours, respectively, for both feces and carcass samples. Two or three suspected colonies of Salmonella from each plate were collected for presumptive identification by biochemistry tests. The media utilized for presumptive identification were: Triple Sugar Iron slant agar (TSI); Lysine-Iron slant agar (LIA); Sulfur Indol Motility agar (SIM), and the Citrate test. Tubes were incubated at $37^{\circ} \mathrm{C}$ for 24 hours. Colonies with biochemistry profile of Salmonella 
Oliveira WF, Cardoso WM, Salles

RPR, Romão JM, Teixeira RSC,

Câmara SR, Siqueira AA, Marques

LCL

were submitted to serologic tests by the use of polyvalent serum against $\mathrm{O}$ and $\mathrm{H}$ Salmonella antigens. The colonies that agglutinated during the period of one to two minutes were considered as positive for Salmonella, and were preserved in Nutrient agar. Isolates were submitted to Adolfo Lutz Institute in São Paulo, Brazil, for complete identification and serotyping.

\section{Antimicrobial sensitivity test}

The behavior of all isolated of Salmonella sp. strains was checked as to the action of antimicrobial drugs. Strains were submitted to sensitivity tests according to the BAUER-KIRBY method (Bauer et al., 1966). Each strain was inoculated in $\mathrm{BHI}$ (brain and heart infusion) broth, and after 24 hours of incubation at $37^{\circ} \mathrm{C}$ they were streaked using sterile swabs on Mueller-Hinton agar plates. Plates were kept in environmental temperature for a period of five minutes, and then diffusion disks with antimicrobial drugs were distributed on the plates and incubated for 24 hours at $37^{\circ} \mathrm{C}$. The antimicrobial drugs were: Ampicillin $(10 \mathrm{mg})$; Amoxycillin (10 mg); Amikacin (30 mg); Norfloxacin (10 $\mathrm{mg}$ ); Tetracycline (30 mg); Chloramphenicol (30 mg); Netilmycin (30 mg); Gentamycin (10 mg); Sufonamide (300 mg), and Carbenicillin (100 mg). Results were interpreted by measuring inhibition zones with the use of a millimeter scale rule. The results were presented as resistant or sensitive according to National Committee for Clinical Laboratory Standards (NCCLS, 2000).

\section{Statistical Analysis}

Companies and categories of carcasses were compared using the Chi-square $\left(x^{2}\right)$ non-parametric test for qualitative analysis at a probability of $5 \%(p<0.05)$.

\section{RESULTS}

The presence of Salmonella spp. was investigated in 63 excreta samples of 21 flocks in three different live production stages. No Salmonella isolated from any of the samples, thereby characterizing the analyzed flocks as free from Salmonella infection.
Initial Identification and Sensitivity to Antimicrobial Agents of Salmonella sp. Isolated from Poultry Products in the State of Ceara, Brazil

Salmonella was isolated in all categories of analyzed broiler carcasses, as shown in Table 1.

In fresh carcass samples, Salmonella panama $(14.3 \%)$ was isolated. Refrigerated carcasses showed a high rate of contamination with Salmonella enteritidis and Salmonella newport (16.7\%). Frozen carcasses showed the lowest contamination rate, with the isolation of Salmonella enteritidis (5.26\%). Salmonella contamination among carcass samples varied; however, these differences were not statistically significant $(p<0.05 \%)$.

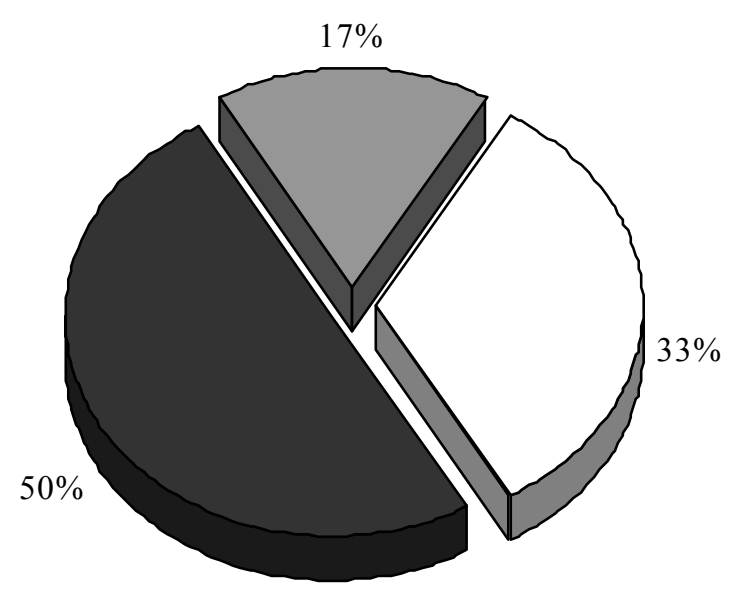

S. Enteritidis

$\square S$. Newport

$\square$ S. Panama

Graph 1 - Percentage of Salmonella strains isolated in broiler carcasses.

Among all the isolated strains, Salmonella enteritidis presented the highest rate of isolation (50\%), followed by Salmonella panama (33.3\%) and Salmonella newport (16.6\%).

The results of antimicrobial sensibility tests are presented in Table 2. The behavior of the isolated strains from broiler carcasses relative to the action of antibiotics showed that all the isolated strains were resistant to Ampicillin and Tetracyclin. Four isolates (Salmonella panama -1 and Salmonella enteritidis -3) were resistant to Amoxycillin. Three isolates (Salmonella panama -1 and Salmonella enteritidis -2)

\begin{tabular}{|c|c|c|c|}
\hline Carcasses & Isolation (\%) & Samples $\left(n^{1}\right)$ & Isolated strains $\left(n^{2}\right)$ \\
\hline Fresh & $2(14.3)$ & 14 & S. panama (2) \\
\hline Refrigerated & $3(16.7)$ & 18 & S. newport (1); S. enteritidis (2) \\
\hline Frozen & $1(5.26)$ & 19 & S. enteritidis (1) \\
\hline Total & $6(11.8)$ & 51 & S. enteritidis (3); S. panama (2); S. newport (1); \\
\hline
\end{tabular}

$n$ - number of samples. Not statistically different $(p<0.05 \%)$. 
Oliveira WF, Cardoso WM, Salles

RPR, Romão JM, Teixeira RSC, Câmara SR, Siqueira AA, Marques LCL

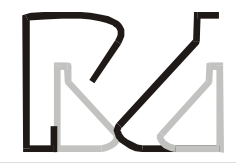

Initial Identification and Sensitivity to Antimicrobial Agents of Salmonella sp. Isolated from Poultry Products in the State of Ceara, Brazil

\begin{tabular}{|c|c|c|c|c|c|c|c|c|c|c|c|}
\hline \multirow[t]{2}{*}{ Salmonella } & \multirow[t]{2}{*}{ N. of samples } & \multicolumn{10}{|c|}{ Resistance to antibiotics $(\mu \mathrm{g})$} \\
\hline & & AMP(10) & TET(30) & AMO(10) & AMI(30) & GEN(10) & NET(30) & SUF(300) & NOR(10) & CLO(30) & CAR(100) \\
\hline Panama & 2 & 2 & 2 & 1 & - & - & - & 1 & 1 & - & - \\
\hline Newport & 1 & 1 & 1 & - & - & - & - & - & - & - & - \\
\hline Enteritidis & 3 & 3 & 3 & 3 & 1 & - & - & 2 & - & - & - \\
\hline Total (\%) & 100,0 & 100,0 & 100,0 & 66,7 & 16,7 & - & - & 50,0 & 16,7 & - & - \\
\hline
\end{tabular}

Legend: AMP - Ampicillin, TET - Tetracycline, AMO - Amoxycillin, AMI - Amikacin, GEN - Gentamycin, NET - Netilmycin, SUF - Sulfonamide, NOR - Norfloxacin, CLO - Chloramphenicol, CAR - Carbenicillin.

were resistant to Sulfonamide, while only one isolate of Salmonella enteritidis presented resistance to Amikacin, and one isolate of Salmonella panama presented resistance to Norfloxacin.

\section{DISCUSSION}

Salmonella is one of the most important sources of food-borne illness in humans, mainly due to the complexity of Salmonellosis epidemiology (Zancan et al. 2000). Broiler meat is a high risk product, according to Berchieri (2000), and production systems and processing facilitate the presence of Salmonella in the final product.

There are several methods to verify the contamination of Salmonella in samples (Read et al. 1994). The bacterial analysis of excreta is a sensitive test (Aho, 1992), and present better results as compared to the methods using cloacal swabs and antibody research in avian serum. Other advantages are that it does not cause stress, and is more representative of bird contamination (Giessen et al. 1991). The absence of Salmonella in the 63 excreta samples from broiler flocks produced in the state of Ceará implies that management and hygiene are good in these farms. These results are in agreement with Moreira (2002), who did not find Salmonella in day old broiler chicks reared by poultry companies in the same region. However, Gama (2001) found Salmonella enteritidis contamination in commercial layer chicks, and Zancan et al. (2000) verified $44.45 \%$ of Salmonella contamination in the transport boxes of commercial layer chicks.

On the other hand, all carcass categories (fresh, refrigerated, and frozen) presented some kind of contamination, as shown in Table 1.

Salmonella panama was isolated in $14.3 \%$ of the fresh carcasses. In refrigerated carcasses, there was a high level of contamination (16.7\%) with Salmonella enteritidis and Salmonella newport. The lower rate of contamination occurred in frozen carcasses (5.26\%) with the isolation of Salmonella enteritidis. The total rate of Salmonella contamination of broiler carcasses was $11.8 \%$, which is considered high, The Codex Alimentarius established $0 \%$ contamination in $25 \mathrm{~g}$ of analyzed food, including poultry meat and eggs (Santos et al., 2000). This percentage is lower than that found by Santos et al. (2000), with 32\% of contamination; by Machado \& Bernardo (1990), with $57 \%$ of contamination; by Plummer et al. (1995), with 23\%; and Arvanitidou et al. (1998), with 69\%. Our results are consistent with the percentage verified by Sharma (1992), with $9.21 \%$ of contamination of broiler carcasses. However, our findings are higher than those reported by Verde et al. (2003), who found 3.6\% of Salmonella contamination in broiler carcasses, and of the USDA, which reported that the national pathogenreduction program reduced the incidence of Salmonella contamination in broiler carcasses to less than $10 \%$ in 2000 (Food, 2000).

The presence of Salmonella panama $(14.3 \%)$ in fresh broiler carcasses and the high rate of Salmonella enteritidis and Salmonella newport in refrigerated broiler carcasses indicates that processing must be better controlled. Navarro (1995) asserts that the number of food-borne disease increased considerably in Central and South America, mainly due to Salmonella enteritidis (Santos et al., 2000). The importance of the workers in the processing line was studied by several authors, as the lack of hygiene favors the dissemination of contamination of broiler surfaces. Pether \& Gilbert (1971) analyzed the level of dissemination of Salmonella anatum by the extremity of fingers from previously infected human volunteers. They verified that the isolation of Salmonella from the finger extremity of these people was directly proportional to the inoculated bacterial population; the results were $100 \%$ positive for $10^{6}$ inoculated bacteria, and 30\% for the interval of $10^{3}$ to $10^{4}$ inoculated bacteria.

The isolated strains in refrigerated carcasses wereSalmonella newport in one case, and Salmonella enteritidis in the two other cases. This represents a significant contamination risk, as many authors report that Salmonella enteritidis, among the genus 
Oliveira WF, Cardoso WM, Salles

RPR, Romão JM, Teixeira RSC,

Câmara SR, Siqueira AA, Marques

LCL
Initial Identification and Sensitivity to Antimicrobial Agents of Salmonella sp. Isolated from Poultry Products in the State of Ceara, Brazil
Salmonella, is the main source of food-borne diseases (Banatvala et al., 1999; Ferris et al., 1999; Plummer et al., 1995; Rodrigues et al., 1990). According to Costa et al. (1996), refrigerated carcasses present high levels of contamination, whereas there are few reports of Salmonella in frozen carcasses. Santos et al. (2003) verified that, out of 272 isolates of Salmonella, 111 were found in frozen carcasses, 126 in food and biological human material involved with cases of foodborne diseases, and 35 in different poultry materials, with the phage type 4 as the most prevalent bacterium. Roberts (1982) observed 80\% contamination in frozen carcasses. This result and our experiment indicate the possibility that broiler carcasses, including frozen carcasses, to disseminate Salmonella to humans; however, Foster \& Mead (1976) assert that the carcass freezing decreases or impairs the survival of the Enterobacteriaceae family.

Among isolated and characterized strains (Graph 1), Salmonella newport presented the lowest isolation rate in broiler carcasses. According to Uyttendaele et al. (1998), Salmonella newport was the most prevalent Salmonella isolated in turkeys, and this serotype is not commonly isolated from chickens (Bokanyi et al., 1990; Ferris et al., 1999; Poppe et al., 1998; Read et al., 1994). Salmonella enteritidis was the most prevalent isolate in the present experiment $(50 \%)$. This result is consistent with the findings of Santos et al. (2003), and Rodrigues et al. (1990). Kinde et al. (1997) found seven isolates of Salmonella enteritidis out of 683 isolated strains in waste water from processing plants located in different districts of California. Other contamination sources were described by other authors, such Cortinez et al. (1995), who isolated Salmonella newport and Salmonella panama from river water samples in Argentina, and Hofer et al. (2000), who isolated these serotypes in horse meat in the Northeast Region of Brazil.

Salmonella strains resistant to antibiotics are commonly found, and this may be due to the comprehensive use of antibiotics included in feeds as growth promoters. The results of the antimicrobial sensitivity tests carried out in the present experiment are alarming, as all isolates showed $100 \%$ resistance to Ampicillin and Tetracycline. These results agree with the findings of Cortinez et al. (1995), who found strains sensitive to Gentamicin and Chloramphenicol, and resistant to Tetracycline. Berchieri et al. (1983) verified $77 \%$ resistance to Tetracycline of Salmonella in poultry feed, and Antunes et al. (2003) found 36\% of Salmonella strains resistant to Tetracycline in broiler carcasses. Bokanyi et al. (1990), Lee et al. (1993), and Nascimento et al. (1997) showed similar results, with $100 \%$ of sensitivity to Chloramphenicol in broiler carcasses. Lee et al. (1993) and Santos et al. (2000) found $100 \%$ of resistance to Ampicillin of Salmonella in broiler carcasses. Our results showed that $66.7 \%$ of isolates were resistant to Amoxycillin, while Antunes et al. (2003) found $19 \%, 19 \%$, and $3 \%$ of resistance to Amoxycillin, Carbenicillin and Chloramphenicol, respectively. The low isolation rates of Salmonella strains resistant to sulfonamide is consistent with Arvanitidou et al. (1998), who found $19.35 \%$ of resistance to Ampicillin, and few strains were resistant to sulfafurazole in chicken carcasses.

According to our results, broilers evaluated during live production in farms located in the state of Ceará presented good microbiological quality in terms of Salmonella infection; however, there was a marked decrease of the microbiological quality of poultry products analyzed in this experiment. As to antimicrobial sensitivity tests, the results were alarming, because $100 \%$ of the isolates were resistant to Ampicillin and Tetracycline.

\section{REFERENCES}

Aho M. Problems of Salmonella sampling. International Journal of Food Microbiology 1992; 15:225-235.

Antunes P, Cristina R, Sousa JC, Peixe L, Pestana N. Incidence of Salmonella from poultry products and their susceptibility to antimicrobial agents. International Journal of Food Microbiology 2003; 82:97-103.

Arvanitidou M, Tsakris A, Sofianou D, Katsouyannopoulos V. Antimicrobial resistance and R-factor transfer of salmonellae isolated from chicken carcasses in Greek hospitals. International Journal of Food Microbiology 1998; 40:197-201.

Banatvala N, Cramp A, Jones IR, Feldman RA. Salmonellosis in North Thames (East), UK: Associated risk factors. Epidemiology and Infection 1999;122:201-207.

Bauer AW, Kirby WMM, Sherris JC, Turck M. Antibiotic susceptibility testing by a standardized single disk method. American Journal Clinic Pathology 1966; 45:493-496.

Berchieri Jr A. Contaminação por Salmonella em farinhas de origem animal utilizadas no preparo de ração. São Paulo (SP): USP; 1983, [Master Dissertation]. São Paulo (SP): Instituição de Ciências Biomédicas, USP; 1983.

Berchieri Jr A. Salmoneloses aviárias. In: Berchieri JrA, Macari M editor. Doenças das aves. Campinas: FACTA; 2000. p.185-196.

Bokanyi RP, Stephens JF, Foster DN. Isolation and characterization 
of Salmonella from broiler carcasses or parts. Poultry Science 1990; 69:592-598.

Bokanyi RP Jr, Stephens JF, Foster DN. Isolation and characterization of Salmonella from broiler carcasses or parts. Poultry Science 1990; 69:592-598.

Brasil. Portaria SDA n 126, de 03 de setembro de 1995. Aprova as normas de credenciamento e monitoramento de Laboratórios de Diagnóstico das Salmonelas aviárias (S. enteritidis, S. gallinarum, S. pullorum e S. tyhimurium). Diário Oficial da União, Brasília, n.212, p.17694-17698, de 6 de novembro, seção I.

Bryan FL, Doyle MP. Health risks and consequences of Salmonella and Campylobacter jejuni in raw poultry. Journal of Food Protection 1995; 58:326-344.

Cortinez IJM, Velasquez LDC, Escudero ME, Caffer MI, Cobo MF, Guzman AMS. Salmonella serotypes from surface waters in San Luis, Argentina. Revista Microbiologia São Paulo 1995; 26:180185.

Costa FN. Sorotipos de Salmonella em carcaças e cortes de frango obtidos na indústria e no comércio e comportamento das cepas isoladas frente à ação de antimicrobianos. [Master dissertation]. Jaboticabal (SP): Faculdade de Ciências Agrárias e Veterinárias; UNESP; 1996. $82 \mathrm{p}$

Cox NA, Mercuri AJ, Tanner DA, Carson MO, Thomson JE, Bailey JS. Effectiveness of sampling methods for Salmonella detection on processed broilers. Journal Food Protection, Des Moines 1978; 41:341-343.

Dhillon AS, Shivaprasad HL, Roy P, Alisantosa B, Schaberg D, Johnson S. Pathogenicity of Environmental Origin Salmonella in Specific Pathogen - Free Chicks. Poultry Science 2001; 80:1323-1328.

Ferris KE, Fisher SD, Flugrad BR, Timm JM. Salmonella serotypes from animals and related sources reported during July 1998. In: Proceedings of the $103^{\text {rd }}$ Annual Meeting of the United States Animal Health Association; 1999; San Diego, CA. p.488-507.

Food Safety and Inspection Service - FSIS. Interim progress report on Salmonella testing of raw meat and poultry products. Washington; 2000.

Forster RD, Mead GC. Effect of temperature and added polyphosphate on the survival of salmonellae in poultry meat during cold storage. Journal of Applied Bacteriology 1976; 41:504-510.

Gama NMSQ. Salmonella spp em aves de postura comercial [Master dissertation]. Jaboticabal (SP): Faculdade de Ciências Agrárias e Veterinárias, UNESP; 2001.

Giessen AW, Peters R, Berkers PA, Jansen WH, Notermans SH. Salmonella contamination of poultry flocks in the Netherlands. Veterinary Quaterly 1991; 13:41-46.

Hinton M. Salmonella infection in Chicks Following the Consumption of Artificially Contamined Feed. Epidemiology and Infection 1988; 100:247-256.
Hofer E, Zamora MRN, Lopes AE, Moura AMC, Araújo HL, Leite MDD, Filho SJS. Sorovares de Salmonella em carne de eqüídeos abatidos no nordeste do Brasil. Pesquisa Veterinária Brasileira 2000; 20:80-84.

Hong'ombe BM, Sharma RN, Skjerve E, Tuchili LM. Occurrence of Salmonella enteritidis in Pooled Table Eggs and Market Ready Chicken Carcasses in Zambia. Avian Diseases 1999; 43:597-599.

Kinde A, Adelson A, Ardans A, Little EH, Willoughby D, Berchtold $D$, Read DH, Breitmeuer R, Kerr D, Tarbell R, Hughes E. Prevalence of Salmonella in Municipal Sewage Treatment Plant Effluents in Sourthern California. Avian Disease 1997; 41:392-398.

Lax AJ, Barrow PA, Jones PW, Wallis TS. Current Perspectives in Salmonellosis. British Veterinary Journal 1995; 151:351-377.

Lee LA, Threatt VL, Puhr ND, Levine P, Ferris K, Tauxe RV. Antimicrobial-resistant Salmonella spp. isolated from healthy broiler chickens after slaughter. Journal of the American Veterinary Medical Association 1993; 202:752-755.

Machado J, Bernardo F. Prevalence of Salmonella in chicken carcasses in Portugal. Journal of Applied Bacteriology 1990; 69:477-480.

Mead PS, Slutsker L, Diet V, McCaig LF, Bresee JS, Shapiro C, Griffin PM, Tauxe RV. Food-related illness and death in the United States. Emerging Infectious Diseases 1999; 5:607-625.

Moreira APO. Pesquisa de Salmonella sp. em frangos de corte de um dia de idade da Região Metropolitana de Fortaleza [Master dissertation]. Fortaleza (CE): UECE; 2002.

Nascimento VP, Cardoso MO, Ribeiro AR, Santos LR, Silva AB, Pontes AP, Oliveira SD. Prevalência e perfis de resistência de Salmonella isoladas de carcaças de frango frente a antimicrobianos e desinfetantes selecionados. In: XIX Congresso Brasileiro de Microbiologia; 1997; Rio de Janeiro, RJ, Brasil. p.291.

National Comittee for Clinical Laboratory Standards - NCCLS. MIC testing supplemental tables M100 - S10 (M7) 2002. Weyne (Pa); 2002.

Navarro MP. Infecção por Salmonella enteritidis em reprodutoras pesadas na América Latina. In: Conferência APINCO de Ciência e Tecnologia Avícolas; 1995; Curitiba, PR, Brasil. p.7-16.

Oboegbulem SI, Collier PW, Sharp JCM, Reilly WJ. Epidemiological aspects of outbreaks of food-borne salmonellosis in Scotland between 1980 and 1989. Revue scientifique et technique 1993; 12:957-967.

PATHOGEN reduction; hazard analysis and critical control point (HACCP) systems. Federal Register, 1995; 60(143):6774-6889.

Pether JVS, Gilbert RJ. The survivals of salmonellas on fingertips and transfer of the organisms to food. The Journal of Hygiene $1971 ; 69: 673-681$

Plummer RAS, Blissett SJ, Dodd CER. Salmonella contamination of retail chicken products sold in UK. Journal of Food Protection 1995; 58:843-846. 
Poppe C, Duncan CL, Mazzocco A. Salmonella contamination of hatching and table eggs: a comparison. Canandian Journal of Veterinary Research 1998; 62:191-198.

Read SC, Irwin RJ, Poppe C, Harris J. A comparison of two methods for isolation of Salmonella from poultry litter samples. Poultry Science. 1994; 73:1617-1621.

Roberts T. Factors contributing to outbreaks of food poisoning in England and Wales 1970-1979. The Journal of Hygiene 1982; 89:491-498.

Rodrigues DC, Taxue RV, Rowe B. International increase in Salmonella enteritidis: A new pandemic? Epidemiology and Infection 1990; 105:21-27.

Santos DMS, Berchieri Jr A, Fernandes SA, Tavechio AT, Amaral LA. Salmonella em Carcaças de Frango Congeladas. Pesquisa Veterinária Brasileira 2000; 20:39-42.

Santos LR, Nascimento VP, Oliveira SD, Rodrigues DP, Reis EMF, Ribeiro AR, Fernandes SA. Phagetypes of Salmonella enteritidis isolated from clinical end food samples, and from broiler carcasses in southern Brazil. Revista do Instituto de Medicina Tropical de São Paulo 2003; 45:1-4.

Scuderi G, Fantasia M, Filetici E, Anastásio MP. Foodborne outbreaks caused by salmonella in Italy, 1991-1994. Epidemiology and Infection 1996; 116:257-265.

Sharma VD. Salmonella contamination of foods of animal origin. In: Salmonella and Salmonellosis Symposium; 1992; Ploufragan, FR. p137-138.

Skov MN, Feld NC, Carstensen B, Madsen M. The Serologic Response to Salmonella typhimurium in Experimentally Infected Chickens, Followed by an Indirect Lipopolysaccharide Enzime - Linked Immunosorbent Assay and Bacteriologic Examinations Through a One - Year Period. Avian Diseases 2002; 46:265-273.

Uyttendaele MR, Debevere JM, Lips RM, Neyts KD. Prevalence of Salmonella inpoultry carcasses and their products in Belgium. International Journal of Food Microbiology 1998; 40:1-8.

Verde JCL, Bezerra FSBC, Soares MIM, Brito ECO, Santos CD. Monitoramento de Salmonella em carcaça de frango coletados em diversos estabelecimentos comerciais da cidade de Fortaleza. In: XIII Encontro Nacional de Analistas de Alimentos; 2003 jun. 22-25; Rio de Janeiro, RJ, Brasil, 2003. p.164.

Zancan FT, Berchieri Jr A, Fernandes SA, Gama NMSQ. Salmonella investigation in transport boxes of day-old birds. Brazilian Journal of Microbiology 2000; 31:230-232. 